University of Chicago Law School

Chicago Unbound

Public Law and Legal Theory Working Papers

Working Papers

2011

\title{
Rhetoric and Reality in Early American Legal History: A Reply to Gordon Wood
}

Alison LaCroix

Follow this and additional works at: https://chicagounbound.uchicago.edu/public_law_and_legal_theory

Part of the Law Commons

Chicago Unbound includes both works in progress and final versions of articles. Please be aware that a more recent version of this article may be available on Chicago Unbound, SSRN or elsewhere.

\section{Recommended Citation}

Alison LaCroix, "Rhetoric and Reality in Early American Legal History: A Reply to Gordon Wood" (University of Chicago Public Law \& Legal Theory Working Paper No. 356, 2011).

This Working Paper is brought to you for free and open access by the Working Papers at Chicago Unbound. It has been accepted for inclusion in Public Law and Legal Theory Working Papers by an authorized administrator of Chicago Unbound. For more information, please contact unbound@law.uchicago.edu. 


\title{
CHICAGO
}

Public LAW AND Legal THEORY WORKING PAPER NO. 356

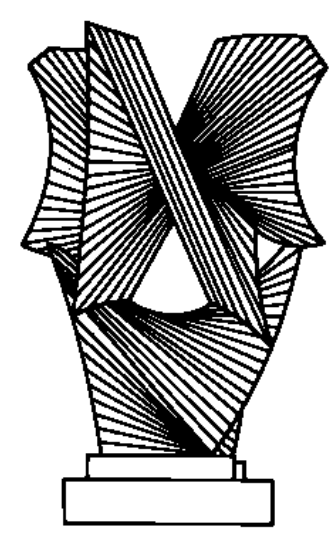

RHETORIC AND REALITY IN EARLY AMERICAN LEGAL HISTORY: A REPLY TO GORDON WOOD

\author{
Alison L. LaCroix \\ THE LAW SCHOOL \\ THE UNIVERSITY OF CHICAGO
}

July 2011

This paper can be downloaded without charge at the Public Law and Legal Theory Working Paper Series: http://www.law.uchicago.edu/academics/publiclaw/index.html and The Social Science Research Network Electronic Paper Collection. 


\title{
REPLY
}

\section{Rhetoric and Reality in Early American Legal History: A Reply to Gordon Wood}

\author{
Alison L. LaCroix $\dagger$
}

\section{INTRODUCTION}

I thank Gordon Wood for his substantive engagement with the arguments in my book, and I welcome the opportunity to exchange views on these major historical and historiographical issues with one of the most important living US historians. There are many places in which we agree, although these might be obscured by the sharp tone of his review. But there are also many points on which we disagree, and I am eager to address those issues.

Wood misstates the main argument of my book. My claim, in its strongest form, is that the debates of the 1760s through the 1780s culminated in a new constitutionalization of federalism, a process that continued into the 1800s. From a disconnected and sometimes ambiguous set of arguments about divided sovereignty in politics, American colonists and early republicans fashioned a new architecture of legal and constitutional authority built on a subject-matter division of governmental power. In contrast to earlier systems - whether formal or informal—of polycentric government, the federalism of the late eighteenth- and early nineteenth-century United States was specifically designed to avoid the ancient problem of imperium in imperio, or dominion within a dominion, that had so troubled the British Atlantic political world for decades. The significant innovation of the American federal idea was to authorize the division of sovereignty and to create viable legal categories that could contain multiple sources of governmental power within one overarching system. ${ }^{1}$

$\dagger \quad$ Professor of Law, The University of Chicago Law School.

I thank David Armitage, William Birdthistle, Adam Cox, Christine Desan, Morton Horwitz, James Kloppenberg, Martha Nussbaum, Lior Strahilevitz, and David Strauss for helpful discussions. I also thank the Mayer Brown Faculty Research Fund for research support.

1 See Alison L. LaCroix, The Ideological Origins of American Federalism 8-10, 133-35, 178-79 (Harvard 2010). 
The intellectual energy of American political and legal thinkers between 1780 and 1800 was thus devoted to a project of translation between political debates and constitutional structure. These statesmen and theorists sought to translate the political conditions of multiple governmental authorities that the colonists had both experienced and theorized under the British Empire into a constitutional structure. This constitutional structure would, they believed, not simply conform to orthodox imperial legal theory through a series of workarounds or legal fictions, but would instead reshape some basic premises of that orthodoxy by rejecting unitary sovereignty in favor of a deep-seated commitment to multiple sources of sovereignty.

In this project of translation, federal theorists such as John Dickinson, John Adams, James Madison, James Wilson, Alexander Hamilton, John Marshall, and others joined experience and theory into a new constellation of operative legal categories. The new constitutional structure celebrated its multiplicity, with the text of the Constitution beating an insistent refrain of overlap, duality, and tension between the states and the general government. The founding document, which both ratified and created the new frame of government, outlined a novel scheme of authority in which the subject of governmental action, not only the actor itself, was the relevant focus for determining legality. Hence the attention to specific categories of subject matter for governmental action: "commerce," "taxation," "treaties, alliances, and confederations." The new republic would escape the imperium in imperio trap by apportioning the powers of government-the subject matters of jurisdiction-between the state and general levels of government. Building on the colonial distinction between internal and external regulation, these thinkers moved beyond previous decades' obsession with identifying a single proper source of political sovereignty and instead reframed the debate around an ideological commitment to a new federal structure, the principal mission of which was to draw the line between the regulatory power of the states and that of the general government while endorsing the importance of each as a distinct sphere of authority. ${ }^{2}$

The localism that Wood insists was central to instilling the colonists with proto-federal beliefs was but one part of a larger, multilayered architecture of governmental authority. Rather than a period in which longestablished colonial practices of town and county autonomy were recast as popular sovereignty in order to be slotted into an existing "logic of sovereignty," ${ }^{3}$ my claim is that the 1770 s and 1780 s were a time of intense

See id at $41-44$ (2011).

Gordon S. Wood, Book Review, Federalism from the Bottom Up, 78 U Chi L Rev 705, 722 
creativity in American constitutional thought. It was not the case that American theorists spent these decades with the ultimate goal of satisfying William Blackstone's theory of unitary sovereignty and that a byproduct of those efforts was a system that only later became preoccupied with the division between sovereigns. The system that they designed was in fact preoccupied with precisely this division.

A view that focuses entirely on unitary sovereignty in this way risks becoming a functionalist account of how political and legal ideas emerge: the Founders' radicalism did not extend to challenging the post-Glorious Revolution orthodoxy of parliamentary sovereignty, so they needed to find a unitary sovereign, so they cast around, found the ideas of popular sovereignty that had been present in Anglo-American political thought since at least the early seventeenth century, and thereby solved the problem of imperium in imperio. But arguments from necessity (people needed a certain idea, so they invented that idea) are an odd version of intellectual history, especially from a scholar widely recognized as one of the leading proponents of a form of history that takes ideas seriously. ${ }^{4}$

My contention is that the Founders rejected the premise of Blackstonian unitary sovereignty, and that their and their colonial forebears' experience with local self-governance was only a part of their broader and - as the debates of the 1760s and 1770s revealed-highly unorthodox vision of governmental authority as capable of division according to the activities, persons, or objects being regulated. ${ }^{5}$ American federal theorists believed that as long as the various imperia were demarcated as the specific domains of either federal or state power (treaties, customs duties, and commerce among the states on the one hand; appointment of presidential electors, selection of US senators, and general police powers on the other), they did not present the type of threat that had so worried Blackstone and theorists such as colonial undersecretary William Knox. The members of the Founding generation viewed their task as accommodating the multiple authorities under which they and their predecessors had lived: the town meeting, the county court, the colony and state, and the imperial and general governments. They therefore understood their task not to be coming to terms with Blackstone's unitary sovereignty but creating a new conception of governmental structure that would both make sense of their

4 See, for example, Gordon S. Wood, The Creation of the American Republic, 1776-1787 viii (North Carolina 1998) ("In essence, republicanism was the ideology of the Enlightenment."). Consider Drew R. McCoy, The Elusive Republic: Political Economy in Jeffersonian America 8 (North Carolina 1980) (citing Wood, along with Bernard Bailyn and J.G.A. Pocock, as setting a scholarly agenda that treats “'republicanism' as a distinctive universe (or 'paradigm') of thought and discourse that gave shape to contemporary perceptions of the American Revolution”).

5 LaCroix, Ideological Origins at 126 (cited in note 1). 
own experience and rise to the level of the English, Scottish, and Continental political theory that they had long studied. ${ }^{6}$

Wood and I disagree about several important elements of Revolutionary and early republican political and legal theory-in particular, and as I discuss below, the relationships between law and social practice and between ideas and experience. These are scholarly disagreements, and they are important. Yet our accounts are not incompatible, despite the apparent determination to find disagreement that Wood's review displays.

\section{FACTS}

Before addressing the substantive issues on which Wood and I disagree, I must first correct some mistaken assertions in his review. As I will demonstrate, many of the asserted missing pieces are in fact covered in the book. A few other issues are not discussed in the text because they are not, in my view, relevant to the story of federalism's development.

First, Wood states that my book "never acknowledges that the American colonists from the very beginning of their settlements in the seventeenth century were thoroughly familiar with the dividing and apportioning of political power." In fact, Chapter 1 of the book begins by noting that many of the antecedents of eighteenth-century federal thought dated from seventeenth-century Anglo-American constitutional debates. ${ }^{8}$ Page 12 contains the following observation: "The lived constitutional experience of many colonists involved multiple lawmaking bodies. For many North Americans, the most significant laws touching everyday activities emanated from their towns or colonial assemblies, not from Parliament or the Privy Council." Wood's assertion is simply incorrect. Indeed, I agree-although perhaps not violently enough for Wood's taste, as in my discussion of the Iroquois Confederacy-that the colonists' experience of divided authority was essential for the development of federal thought.

Second, in another mischaracterization of my argument, Wood maintains that "[a]lthough LaCroix mentions the New England Confederation, she never explains its background. Indeed, she never acknowledges that the idea of parceling out authority from the bottom upcreating different levels of government - was very much a part of American

6 For a persuasive argument that scholars' emphasis on Blackstone's influence on the Founders has obscured other sources of legal theory, and that early eighteenth-century Scottish legal thought had particular importance for the structural provisions of the Constitution, see generally James E. Pfander and Daniel D. Birk, Article III and the Scottish Judiciary, 124 Harv L Rev 1613 (2011).

7 Wood, $78 \mathrm{U}$ Chi L Rev at 710 (cited in note 3).

8 LaCroix, Ideological Origins at 11 (cited in note 1).

9 Id at 12. 
experience from the beginning." ${ }^{10}$ I must confess myself mystified at this dogged misreading of the book. Pages 20-22 of the book discuss the New England Confederation of 1643 in some detail, explaining that the drafters intended the agreement as a "firm and perpetual league of friendship and amity" for the purposes of "preserving and propagating the truth and liberties of the Gospel and for their own safety and welfare." " As for the parceling out of authority "from the bottom up," the book clearly emphasizes the point that confederations among colonies were premised on the colonists' belief that they could themselves legitimately constitute governmental authority. ${ }^{12}$

Third, in his lengthy section on representation, which Wood includes as part of his longer discussion of popular sovereignty (which I treat at length below ${ }^{13}$ ), Wood states that I "ignore[]" the distinctions between actual and virtual representation. ${ }^{14}$ While it is true that the book does not explicitly discuss these theories, it is not the case that they have been ignored. The representation question was certainly important for many of the actors I discuss, but I chose to focus on another limiting argument that the colonists used to cabin Parliament: the distinction between internal, colonial taxes or legislation and external, empire-wide regulation. Both strategies were attempts to redefine the power of Parliament—although, as I discuss below, Wood and I disagree about the range and breadth of possible reforms available to the colonists. Given his emphasis on local legislative autonomy, Wood's focus on representation makes sense, but it is not necessary to my account of structural multiplicity.

Fourth, Wood states that I "scarcely acknowledge[] the existence of William Knox's ministerial pamphlet of 1769 ... even though it was the most important statement of the official British position in the entire period." categorical critique. On pages 52, 63, and 122, and in a footnote on page 243, the book provides several extended quotations from Knox's pamphlet and portrays him as one of the major exponents of the metropolitan perspective on the imperial constitution. Wood would presumably prefer more discussion of Knox because he believes that, along with Blackstone's views on sovereignty, Knox's theories amounted to orthodoxy that the colonists had no choice but to adopt. I disagree.

Fifth, although Wood dismisses the Articles of Confederation as simply an application of long-established local autonomy ("forming the

10 Wood, $78 \mathrm{U}$ Chi L Rev at 715 (cited in note 3) (citation omitted).

11 LaCroix, Ideological Origins at 21 (cited in note 1).

12 Id at 20.

13 See Part II.A.

14 Wood, $78 \mathrm{U}$ Chi L Rev at 717 (cited in note 3).

15 Id at 720. 
Articles of Confederation posed no great theoretical problems"), a few lines later he nevertheless suggests that my account spends too little time on them. ${ }^{16}$ In fact, Chapter 4 contains a detailed discussion of the Articles, describing their content and situating them in the broader context of colonial attempts at union dating from the early seventeenth century. Moreover, had Wood attended to footnote 58 on page 261, he might not have been so quick to assert that "[s]he does not seem to realize that the Confederation Congress was merely a replacement for the Crown." ${ }^{17}$ That note contains a lengthy discussion of Jerrilyn Green Marston's King and Congress, including the following observation: "Marston argues that the text vested the Confederation Congress with many of the most important executive functions for which the Crown had formerly been responsible." ${ }^{\prime 18}$

Sixth, in a moment of constitutional formalism, Wood states that "LaCroix never mentions" Article I, $\S 10$ of the Constitution. ${ }^{19}$ This is an important omission, he feels, because the delegates to the Constitutional Convention regarded $\S 10$ 's list of prohibitions on state power as "the replacement for Madison's veto.” ${ }^{20}$ As the Convention debates demonstrate, however, many delegates viewed the Supreme Court's power of judicial review as the most important substitute for Madison's proposal to give Congress the power to negative state laws. When they discussed Article I, $\S 10$, they regarded it as a legislation-focused complement to the Supremacy Clause's judicial mechanism of keeping the states in check. ${ }^{21}$ Wood's insistence that Article I, § 10, replaced Madison's negative suggests that he has conflated the Founders' debate over the rules by which subject matter was to be allocated with their institutional debate over how those rules would be enforced. But it was through their treatment of the institutional question that the Founders translated their commitment to multiplicity into a new legal form.

Finally, in the last paragraph of the review, Wood laments that I did not "dip[] into" any volumes of the ratification debates. ${ }^{22}$ He grants that the creation of American federalism "involved a great deal of intellectual debate" but then warns that "that debate did not take place in the Constitutional Convention." ${ }^{23}$ Few historians of the period would make such a sweeping, and implausible, claim about the Constitutional Convention. Moreover, the book contains several references to the ratification debates in

16 Id at $724-25$.

17 Id at 724 .

18 LaCroix, Ideological Origins at 261 n 58 (cited in note 1), discussing Jerrilyn Greene Marston, King and Congress: The Transfer of Political Legitimacy, 1774-1776 205 (Princeton 1987).

19 Wood, $78 \mathrm{U}$ Chi L Rev at 727 (cited in note 3).

20 Id at 726.

21 See LaCroix, Ideological Origins at 163 (cited in note 1).

22 Wood, $78 \mathrm{U}$ Chi L Rev at 732 (cited in note 3).

23 Id. 
the form of the Federalist essays, as well as John Marshall's comments on the floor of the Virginia convention, when the future chief justice urged his colleagues to embrace the possibility of a system of inferior federal courts. Taking up Wood's suggestion that the "real" intellectual debate did not take place in the Constitutional Convention, however, I must disagree. Indeed, given Wood's insistence on the importance of the ratification debates, his outright dismissal of the Constitutional Convention is puzzling. In Part II.B, I discuss the Convention's retooling of received political philosophy into a new vision of political authority and finally into a workable legal systemsurely the product of intellectual debate.

Now let us move to more substantive points.

\section{SUBSTANTIVE ClAims}

Although Wood raises a number of issues, I address them under two broad themes: (1) localism and popular sovereignty, and (2) judicial review and the Supremacy Clause.

\section{A. Localism and Popular Sovereignty}

The first third of Wood's review could easily have been titled "The Triumph of William Blackstone" based on the almost evangelical zeal with which Wood not only adopts that jurist's views of sovereignty but also marshals them against the American Founders to show that they could not possibly have held any dissenting views of the proper arrangement of governmental authority. Wood's critique contains three claims: first, that the colonists' dominant political experience centered on "bottom up," locally based political autonomy at the level of the town and the county; second, that this localism was distinct from what he might term the "top down" exercise of British imperial authority over the colonies, as well as the "bottom up" resistance from the colonies against metropolitan authority; and third, that only his species of localism is significant for the development of federalism. This localism, he argues, stemmed from centuries of the "long English heritage of local autonomy" and came to fruition in the Founders' embrace of popular sovereignty as the basis of American government. ${ }^{24}$ For Wood, localism was both sufficient and necessary to bring about federalism. From this view follows the conclusion that the theoretical shift of the 1780s was a mere formalization of localism in the form of a fundamental commitment to popular sovereignty. Federalism, then, was nothing more than the extension of the colonists' experience of localism, a theoretical fillip to the more important reality of rule by the people. 
In laying out this view, Wood omits at least half the story of federalism's origins. Of course the colonists' experience with local autonomy profoundly shaped their political and constitutional worldview by giving them a deeply ingrained sense of governmental power as susceptible to the people's control. Nothing in my book disputes this point, and indeed the book takes as given the importance of these antecedent ideas of local control. In my discussion of the early American confederations, I explain that the articles of confederation among the four colonies of the New England Confederation of 1643 "did not refer to the Crown, Parliament, or any other metropolitan authority. The recitation of authority that began the document referred only to the member colonies and spoke in the language of Calvinist voluntarism." ${ }^{25}$ Assertions of popular sovereignty dating from the English Civil War clearly undergirded these colonists' powerful sense of themselves as possessing the power to establish a government. ${ }^{26}$

As the book makes clear, the earliest efforts at colonial confederation took place within the first three decades of English settlement in mainland North America, and each of these efforts proceeded from the premise that the colonists themselves possessed the power to enter into leagues with other colonies. My argument, therefore, emphasizes both the colonists' belief in the legitimacy of their own locally based constitutional power (what Wood terms "bottom up" political authority ${ }^{27}$ ) and their intuition that this power could reach outside one's own colony to form supracolonial associations with one's neighbor colonies. This latter point is the logical extension of a theory of "bottom-up" political authority. It is what happens when several politically and legally autonomous units join together to create another level of governmental authority.

But such connections are simply ignored in Wood's account. Wood's strange assertion that the book "never acknowledges that the idea of parceling out authority from the bottom up-creating different levels of government-was very much a part of American experience from the beginning” ${ }^{\prime 2}$ demonstrates this unwillingness to conceive of local political autonomy as having any outward-looking consequences. Where Wood sees local political autonomy, therefore, I see local political autonomy as well as the desire within those localities to form bonds, treaties, leagues, and confederations with other localities - that is, the desire to experiment with multiple levels of governmental authority. Colonial legal practice and

25 LaCroix, Ideological Origins at 20-22 (cited in note 1).

26 See, for example, William Clarke, The Putney Debates (Oct 28, 1647), in C.H Firth, ed, 1 The Clarke Papers 226, 301 (Camden Society 1891) (quoting Thomas Rainborow, a colonel in Cromwell's New Model Army, as saying "every man that is to live under a Governement ought first by his owne consent to putt himself under that Governement”).

27 Wood, $78 \mathrm{U}$ Chi L Rev at 711 (cited in note 3).

28 Id at 715. 
theory were thus much messier than Wood's account suggests, and provincial thinkers engaged for decades in efforts to reconcile competing sources of authority: local law and imperial regulation, ordinary legislation and higher law. ${ }^{29}$

Wood baldly asserts that a distinctly and exclusively local species of authority was the only recognized source of legal and political power in the early colonial period. "During the first generation of settlement in the New World, the Crown, which in England was considered the source of all local authority, for all intents and purposes simply did not exist," he states. ${ }^{30}$ Quite the contrary. Consider the opening lines of the Mayflower Compact, one of the earliest acts of political self-determination by a group of colonists:

In the Name of God, Amen. We, whose Names are under-written, the Loyal Subjects of our Dread Soveraign Lord King James. . . Having undertaken for the glory of God, and advancement of the Christian Faith, and the Honour of our K[i]ng and Countrey, a Voyage to plant the first Colony in the Northern parts of Virginia; Do by these Presents, solemnly and mutually, in the presence of God and one another, Covenant and Combine our selves together into a Civil Body Politick. $^{31}$

The spirit of local authority, of direct communion between the people aboard the Mayflower and their God, suffuses this famous founding document. But that covenant with divine authority (the political equivalent of Luther's call for Protestants to interpret biblical text for themselves) was combined with a direct grant of temporal political authority from James I. Indeed, the Mayflower separatists' references to the Stuart king were more than early modern boilerplate, a throat-clearing exercise at the beginning of an official document. The compact not only described the Mayflower passengers as loyal subjects of the monarch, it also listed "the Honour of our King and Countrey" as one of the motivations for their venture. These

29 The argument that British North Americans consciously engaged in a decades-long effort to reconcile competing sources of law, especially positivist versus higher-law-based accounts of ultimate legal authority, received scholarly attention in the middle of the twentieth century and has recently become the subject of renewed examination by legal historians. For two influential accounts, see Joseph Henry Smith, Appeals to the Privy Council from the American Plantations 614, 629-35 (Columbia 1950); J.W. Gough, Fundamental Law in English Constitutional History 192-96 (Oxford 1961). For more recent investigations, see Philip Hamburger, Law and Judicial Duty 31-69, 283-326 (Harvard 2008); Daniel J. Hulsebosch, Constituting Empire: New York and the Transformation of Constitutionalism in the Atlantic World, 1664-1830 75-144 (North Carolina 2005); Mary Sarah Bilder, The Transatlantic Constitution: Colonial Legal Culture and the Empire 186-96 (Harvard 2004). See also R.H. Helmholz, Bonham's Case, Judicial Review, and the Law of Nature, 1 J Legal Analysis 325, 331 (2009).

30 Wood, $78 \mathrm{U}$ Chi L Rev at 712 (cited in note 3).

31 Mayflower Compact (1620), reprinted in Donald S. Lutz, ed, Colonial Origins of the American Constitution: A Documentary History 31, 31-32 (Liberty Fund 1998). 
English settlers claimed the power to combine themselves in a civil body politic, and they understood that body politic to exist in an ongoing relationship with Crown, country, and deity.

The emphasis on predicate sources of political and legal power that was so important for early settlers came to preoccupy many colonists in the middle of the eighteenth century. At that point, the dual tensions in colonial legal thought between, first, positive legislation and higher law, and second, localism and membership in the empire, became manifest. Perhaps no colonial commentator better illustrates British North Americans' efforts to reconcile these competing commitments than James Otis. In a widely circulated 1764 treatise that laid bare the colonists' struggle to articulate a coherent constitutional vision, Otis offered forceful arguments for the ostensibly incompatible theories of popular sovereignty, parliamentary sovereignty, natural law, colonial rights, and colonial subjection to Parliament. "[S]upreme absolute power is originally and ultimately in the people," Otis stated. ${ }^{32}$ This strong endorsement of popular sovereignty was followed by a robust declaration that took a similar line to that of Otis's contemporary, Blackstone: "The power of Parliament is uncontrollable but by themselves, and we must obey. They only can repeal their own acts." ${ }^{33}$ Yet Otis evidently also believed that there were limits to Parliament's uncontrollable authority: "The Parliament cannot make 2 and 2, 5: omnipotency cannot do it.” ${ }^{34}$ Where did these limits come from? Otis then argued for a higher-law boundary on parliamentary authority. "There must be in every instance, a higher authority, viz., GOD. Should an act of Parliament be against any of his natural laws, which are immutably true, their declaration would be ... void.. ${ }^{35}$ The remedy for any such violations, however, appeared to lie with the legislature: "and so it would be adjudged by the Parliament itself when convinced of their mistake., ${ }^{36}$ As for the colonies' relationship to Parliament, Otis stated that "as over subordinate governments the Parliament of Great Britain has an undoubted power and lawful authority to make acts ... that, by naming them, shall and ought to be equally binding as upon the subjects of Great Britain within the realm.” ${ }^{37}$ Along with these duties to Parliament, however, the colonists could claim "all the natural, essential, inherent, and inseparable rights of our fellow subjects in Great Britain.” ${ }^{38}$

\footnotetext{
32 James Otis, The Rights of the British Colonies Asserted and Proved (1764), reprinted in Bernard Bailyn, ed, 1 Pamphlets of the American Revolution 1750-1776 408, 424 (Belknap 1965) (emphasis omitted).

33 Id at 448.

34 Id at 454 .

35 Id (emphasis omitted).

36 Otis, Rights of the British Colonies at 454 (cited in note 32).

37 Id at 442.

38 Id at 444.
} 
What is one to make of this welter of apparently conflicting arguments in Otis's writings? The principal lesson to be drawn is that while the experience of local authority and the theory of popular sovereignty were significant aspects of provincial law and politics, other elements of the colonists' experience and thought were at least as important for the emergence of American federalism. As demonstrated by Otis's anguished attempt to cobble together the disparate elements of post-Glorious Revolution English political theory, higher-law limitations on legislative power, and the colonists' experience of local government, British North Americans clearly felt that their commitment to local political autonomy did not offer complete answers to some of the most pressing issues of colonial law and politics. Many colonial commentators therefore brooded on the preliminary question of establishing the legal legitimacy of the fledgling colonies as well as the later question of placing mature colonies with thriving local political institutions within the framework of a larger empire that was increasingly committed to parliamentary sovereignty.

Here my disagreement with Wood becomes manifest. Wood argues that the colonies were always federal, and he understands "federal" to mean a foundation of local political authority. ${ }^{39}$ The early settlers, he maintains, "were experiencing federalism without any ideological justification whatsoever." "bottom up" political authority from the people in the towns and counties, it never presented a challenge to orthodox British political theory's growing aversion to imperium in imperio. Indeed, Wood claims, it was precisely this deep-seated commitment to localism and popular sovereignty that permitted the colonists - and later the Founders - to satisfy the demands of Blackstone, Knox, and others for unitary, undivided sovereignty. Unitary sovereignty was there all along, vested in the people, so at the moment of crisis, "the people" simply took over from Parliament to become the new single sovereign in American theory. The colonists, Wood insists repeatedly, could not "evade the logic of sovereignty" put forth by Blackstone and Knox; that logic was just too powerful. ${ }^{41}$ "In the end," Wood states, the Massachusetts House of Representatives "accepted the logic of the Blackstonian idea of sovereignty, which is what all the colonial leaders eventually did." ${ }^{\prime 2}$ Indeed, we are told, "[o]ne by one, all of the leading Revolutionaries-John Adams, Thomas Jefferson, Benjamin Franklin, and Alexander Hamilton-accepted the logic of sovereignty but relocated it in their separate legislatures.” ${ }^{43}$

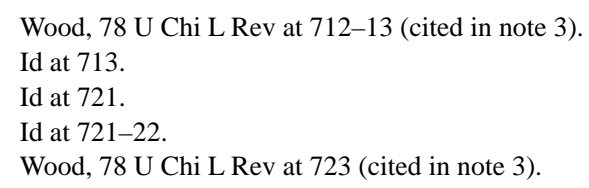


"Accepted the logic"? This does not read as the detached analytical tone of the historian; this is the language of the advocate. With such locutions as "accepted the logic" and "evade the logic," Wood suggests that Blackstone's and Knox's arguments were the only acceptable logic, and that the colonists' early attempts to resist it were just foolish or misguided. If Wood's narrative is based on an unchanging commitment to local autonomy that, in the form of popular sovereignty, simply took the place of Parliament and left the rest of British political and legal orthodoxy unchanged, one wonders whether he believes that anything new emerged from American thought in the 1770s and 1780s. Was the creation of the American Republic, 1776-1787, really nothing more than the clever recasting of a preexisting colonial commitment to local governance in order to satisfy a problem of domestic British political theory? In other words, is Wood taking the position that the unitary view of sovereignty was the correct one, and therefore that the colonists must have accepted it in order to avoid being "wrong on the law"? ?4

Strangely enough, Wood's answer to these questions appears to be yes. ${ }^{45}$ He rejects arguments that the colonists began in the 1770 s to move away from a belief in unitary sovereignty and toward a theory of multiple authorities. "They were, of course, doing nothing of the sort," he states. The force of the Blackstonian argument compelled the colonists to relocate sovereignty to the several colonial legislatures. And lest one think this represented a change, Wood offers the following: "This was an intellectual adjustment, not a substantive one, as Americans had usually acted as if their separate colonial legislatures were miniature parliaments.”47

But in fact an intellectual and a substantive adjustment-a moment of creativity-was exactly what the colonists were engaged in during the 1770 s and 1780s. (Here one must note how odd such a statement is from a scholar who once criticized "behaviorist historians" for treating ideas as "merely a covering superstructure for the underlying and determinative social reality." ${ }^{\prime 4}$ ) Wood's claim that the Blackstone-Knox theory of unitary sovereignty was both descriptively accurate and the only acceptable

\footnotetext{
44 See Barbara A. Black, The Constitution of Empire: The Case for the Colonists, 124 U Pa L Rev 1157, 1157-58 (1976) (critiquing inquiries framed in this way).

45 The unwavering belief in a single, correct "logic of sovereignty" that Wood displays in his review stands in sharp contrast to his previous critiques of scholars whom he viewed as producing "briefs" for the arguments of actors that they studied. See Gordon S. Wood, Ideology and the Origins of Liberal America, 44 Wm \& Mary Q 628, 632-33 (1987) ("It may be a necessary fiction for lawyers and jurists to believe in a 'correct' or 'true' interpretation of the Constitution in order to carry on their business, but we historians have different obligations and aims.”).

46 Wood, $78 \mathrm{U}$ Chi L Rev at 722 (cited in note 3).

47 Id.

48 Gordon S. Wood, Rhetoric and Reality in the American Revolution, 23 Wm \& Mary Q 3, 8 (1966).
} 
normative view at the time attributes a totalizing, hegemonic power to their ideas that is not borne out in the sources. Indeed, Wood's implication that Blackstone and Knox were correct-so much so that attempts by the colonists to refute them amounted to "evad[ing]" their logic or attempting to "get away with denying Parliament's authority to tax them" — risks running afoul of the fallacy Barbara Black described as "refusing to call a Revolution a revolution." ${ }^{50}$

The colonists did not argue for divided sovereignty, Wood insists, because they could not. I maintain that the colonists did argue for divided sovereignty, and that understanding how they managed to do so, and how they drew that new idea from familiar ideas and experiences, is what ought to matter to an intellectual historian. Popular sovereignty was certainly part of the creativity of the period, but the equally significant achievement of these thinkers lay in their reconception of the relationships among institutions and governments themselves.

\section{B. Judicial Review and the Supremacy Clause}

In the book, I argue that the debate in the Constitutional Conventionin particular, the rejection of Madison's negative and the adoption of judicial review under the Supremacy Clause and Article III-was a vital moment for the emergence of American federalism. ${ }^{51}$ In the course of these discussions, including Madison's own research and writing in preparation for the Convention and the ratification debates, federal thought was translated from a diffuse array of theories about, and experiences of, governmental multiplicity to a set of operative legal categories. ${ }^{52}$ Two important and related developments during the Convention characterized this translation: first, an effort to formalize the subject-matter, rather than functional, division of authority among levels of government that had first been articulated by the colonists in the 1760s; and second, a shift in emphasis from legislative to judicial remedies for state misbehavior and parochialism, which many delegates believed posed the greatest threat to the confederation.

The subject-matter-based division of governmental authority underpinned many provisions of the Constitution, in particular Article I, § 8 (setting forth Congress's enumerated powers) and Article I, § 10 (prohibiting the states from regulating certain subjects). ${ }^{53}$ For different reasons, Federalists such as Alexander Hamilton, Gouverneur Morris, and John Marshall, and

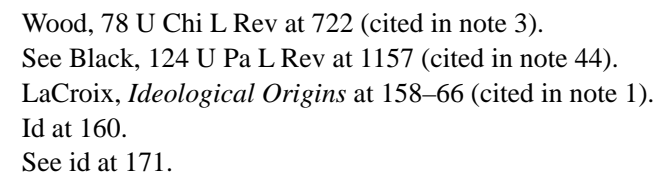


even skeptics such as Thomas Jefferson, shared the sense that an initial allocation of power between the states and the general government was essential to avoiding the old imperium in imperio problem. ${ }^{54}$ The provisions of Article I, § 10, all of which were addressed to the state legislatures, were a first step in this project. But the ultimate weapon against messy overlap between state and federal levels of government was to be the courts. ${ }^{55}$ In response to Madison's negative, Jefferson argued for "an appeal from the state judicature to a federal court, in all cases where the act of Confederation controled the question.” Would not a judicial mechanism such as this, he inquired, "be as effectual a remedy, \& exactly commensurate to the defect?" ${ }^{56}$

Just as many critics of imperial regulation had argued in the 1760s, the key theoretical move was not to find a new unitary sovereign but to conceive that it was possible — even desirable-for one polity to contain multiple sovereigns, as long as each was prescribed a specific regulatory domain in which to exercise its power. In the 1760s, the distinction between internal and external regulation was one important mode by which the colonists began to think through subject-matter-based authority. The contribution of the debates in the 1780s was to support this newly legitimized structure of legislative multiplicity with a set of institutions designed to police the boundaries between the power of the states and that of the general government. These institutions were, of course, courts in general (all of which were bound by the Supremacy Clause), and federal courts in particular (as envisioned by the Federalists and enacted by the First Congress in the Judiciary Act of $1789^{57}$ ). The Constitution drew the lines of authority and also established the institutions that would monitor these boundaries in perpetuity. ${ }^{58}$

Wood resists the notion that the defeat of Madison's negative was a turning point in the development of federalism, as well as the related idea that the defeat of the negative had anything to do with the eventual adoption of judicial review of state courts' decisions or state legislatures' acts. Again, Wood insists that the Founders' experience of popular sovereignty was the central-indeed, the only-force motivating their decisions during the drafting and ratification of the Constitution. He reads the argument for judicial review offered in Federalist 78 as Hamilton "simply trying to

4 See id at $179-213$

55 See LaCroix, Ideological Origins at 163 (cited in note 1).

56 Letter from Thomas Jefferson to James Madison (June 20, 1787), reprinted in Robert A. Rutland, et al, eds, 10 The Papers of James Madison 63, 64 (Chicago 1977).

571 Stat 73.

58 See LaCroix, Ideological Origins at 165 (cited in note 1). 
establish and enhance the independence and authority of the judiciary against the mistrusted state legislatures." ${ }^{59}$

This interpretation of Federalist 78 demonstrates the limits of an approach that reads the Founding period entirely, and only, through the lens of popular sovereignty. Hamilton justified judicial review as the mechanism by which the courts would serve as "an intermediate body between the people and the legislature, in order, among other things, to keep the latter within the limits assigned to their authority." ${ }^{\prime 0}$ Institutions mattered to Hamilton. The point of Federalist 78 was not only to establish the legitimacy of the courts by linking them to the people but also to vest the judiciary with ultimate guardianship of the Constitution.

In making this argument, Hamilton offered a theoretical justification not only for judicial review, but also for a view of judicial supremacy that associated courts - in particular, the Supreme Court-with the Constitution itself. ${ }^{61}$ Federalist 78 explicitly linked the judiciary with the people, but the larger connection that Hamilton made was the one between the judiciary and the Constitution as the preeminent source of higher law. "No legislative act [ ] contrary to the constitution can be valid," Hamilton wrote. ${ }^{62}$ Such a principle supposes that

where the will of the legislature declared in its statutes, stands in opposition to that of the people declared in the constitution, the judges ought to be governed by the latter, rather than the former. They ought to regulate their decisions by the fundamental laws, rather than by those which are not fundamental. ${ }^{63}$

To be sure, he went on to say that to argue otherwise would be "to affirm ... that the representatives of the people are superior to the people themselves." ${ }^{\prime 4}$ The people and the Constitution were deeply intertwined. But the invocation of the Constitution as both a source of governmental power and as the government itself was new in the 1780s and was therefore not part of the seventeenth- and early eighteenth-century colonial experience that Wood argues was the fount of American federalism.

Hamilton's vision of judicial review thus aimed to solve the puzzle that had tormented James Otis: Were there any limits to the power of an

59 Wood, 78 U Chi L Rev at 731 (cited in note 3).

60 Federalist 78 (Hamilton), in The Federalist 521, 525 (Wesleyan 1961) (Jacob E. Cooke, ed).

61 Contemporary observers as well as modern scholars have read Federalist 78 as making the case for judicial supremacy. See, for example, Jack N. Rakove, Original Meanings: Politics and Ideas in the Making of the Constitution 186 (Vintage 1996) (noting Anti-Federalists' critique of Federalist 78 as giving the federal judiciary "a final power of interpreting the meaning of the Constitution and the laws").

62 Federalist 78 (Hamilton) at 524 (cited in note 60).

63 Id at 525.

64 Id at 524. 
omnipotent legislature? If so, those limits must come from a higher source of law. Otis had worked through the arguments and come to the ambiguous conclusion that although Parliament's authority must be limited by natural law (it could not make 2 plus 2 equal 5), it was not clear what, if any, institution could enforce these limits against the legislature. Hamilton provided a theoretical and practical solution to this problem: the legislature was not sovereign; the people were sovereign. And the institution that would enact this amorphous popular sovereignty was the judiciary. Popular sovereignty was certainly important to Hamilton, but the idea of the Constitution as higher law in and of itself was beginning to take on normative power. ${ }^{65}$ While Otis had struggled to articulate the means by which "God and nature" could provide real limits on Parliament, rather than simply leaving its subjects waiting in the hope that Parliament would suddenly be "convinced of [its] mistake," ${ }^{66}$ Hamilton gave the ethereal Constitution concrete force by vesting the courts with the institutional responsibility for guarding and carrying out the Constitution in the here and now. Courts, therefore, would police the actions of the legislatures to ensure that fleeting majorities could not damage the perpetual Constitution. By standing in for the Constitution, courts would also provide a way out of the head-to-head conflict between legislatures that had for decades elicited charges of imperium in imperio. The Constitution was understood to embody the people, but for Hamilton and his fellow Federalists, it was also a source of law and a roadmap for dividing governmental authority.

I therefore agree with what many scholars have long taken to be one of the central arguments in Wood's Creation of the American Republic: that the shift from legislative to popular sovereignty around 1787-1789, as described in Federalist 78, helped Americans finally to break free of their long-established fears of imperium in imperio ${ }^{67}$ But I do not agree with the Wood of this review, insofar as he insists that Federalist 78 was nothing more than a restatement of a decades-old commitment to "bottom up" political authority. British North Americans certainly had experimented with local autonomy for decades, but they had also conducted a long struggle to reconcile their commitment to localism with their mutually incompatible beliefs in legislative sovereignty and higher-law limits on legislatures. With the negative, Madison attempted to graft a key element of imperial practice-hierarchical legislative review-onto the two-tiered structure of the Confederation. Madison's proposal thus echoed the debates

65 Consider Morton J. Horwitz, A Historiography of the People Themselves and Popular Constitutionalism, 81 Chi Kent L Rev 813, 817 (2006) (noting that for both Wood and Bernard Bailyn, "the emergence of the idea of a Constitution as embodying fundamental law is one of the paramount achievements of the American Revolution").

66 Otis, Rights of the British Colonies at 446 (cited in note 32).

67 Wood, Creation of the American Republic at 372-89 (cited in note 4). 
of the 1760s and 1770s, which focused exclusively on the relationship between legislatures (there, the colonial assemblies and Parliament; in the 1780s, the state legislatures and Congress). The delegates' rejection of the negative, followed immediately by their taking up a draft provision directing that "the Judiciaries of the several States" would be "bound" by "the supreme law" of the United States, signaled that the institutional focus of federal thought was shifting from legislatures to courts. ${ }^{68}$

This is not to say, however, that judicial review was entirely novel in the 1780s. On the contrary: a large body of scholarship dating from the early twentieth century, and recently updated with nuanced additions to the historiography, makes clear that judicial review-meaning the ability of courts to pass on the validity of statutes-was a long-established practice in English and Anglo-American law. ${ }^{69}$ Wood's claim that judicial review did not emerge until decades after the Founding echoes an old strain of Marbury-worship in constitutional law scholarship, but it is simply not supported by the evidence, and modern historiography has decidedly rejected this view. ${ }^{70}$ Many decades before Marbury $v$ Madison $^{71}$ and Fletcher $v$ Peck $^{72}$ established the Supreme Court's power to invalidate acts of Congress and state laws, Anglo-American lawyers and statesmen believed that courts had the power to strike down-or, in more modest terms, to recognize the voidness of-laws that did not conform to the fundamental law of the land. As Philip Hamburger observes, "Long before Americans declared their independence, many English lawyers understood that the law made by the people, their 'constitution,' was of higher authority and

68 Wood notes that this draft version of what became the Supremacy Clause was introduced by Luther Martin, who opposed the creation of inferior federal courts. Wood seems to intend this observation as evidence that Martin's proposal could not possibly have been made with judicial review in mind. As I demonstrate in Chapter 6 and in a forthcoming article, however, opponents of federal courts frequently embraced the requirement that state court judges be "bound" by federal law because the ambiguity of the phrase arguably left some authority in the hands of state judges. See LaCroix, Ideological Origins at 196 (cited in note 1). See also Alison L. LaCroix, Federalists, Federalism, and Federal Jurisdiction, 30 L \& Hist Rev *5-6 (forthcoming 2012), online at http://ssrn.com/abstract=1558612 (visited Apr 16, 2011).

69 See Smith, Appeals to the Privy Council at 523-52 (cited in note 29); Julius Goebel Jr, 1 History of the Supreme Court of the United States: Antecedents and Beginnings to 180150 (Macmillan 2d ed 1971); William E. Nelson, Changing Conceptions of Judicial Review: The Evolution of Constitutional Theory in the States, 1790-1860, 120 U Pa L Rev 1166, 1166-68 (1972); Hulsebosch, Constituting Empire at 28-31 (cited in note 29); Bilder, The Transatlantic Constitution at 186-87 (cited in note 29); Hamburger, Law and Judicial Duty at 179 (cited in note 29). See generally Jack N. Rakove, The Origins of Judicial Review: A Plea for New Contexts, 49 Stan L Rev 1031 (1997).

70 Compare Alexander M. Bickel, The Least Dangerous Branch 1 (Yale 2d ed 1986) (asserting that the Constitution solidified the duties of Congress and the President but that Chief Justice John Marshall's opinion in Marbury $v$ Madison "summoned [the judiciary] up out of the constitutional vapors"), with Rakove, 49 Stan L Rev at 1036 (cited in note 69) (criticizing Bickel's "dramatic theory of the Pallas-Athena birth of judicial review" by rooting judicial review in Article VI and citing its long historical record).

715 US (1 Cranch) 137 (1803).

7210 US (6 Cranch) 87 (1810). 
obligation than other human law in their jurisdiction." ${ }^{\text {73 }}$ Although the idea remained vague, it was certainly familiar to many educated British North Americans, especially those present at the Constitutional Convention. ${ }^{74}$

As the debate over Madison's negative demonstrates, the primary focus of the discussion about judicial review in the 1780s was the Supreme Court's review of state legislative acts and state court decisions, not review of acts of Congress. The delegates' rejection of the negative, followed later that day by their adoption of the draft Supremacy Clause, marked a decisive shift from decades-long debates about which legislature was supreme to a reliance on courts as referees charged with ensuring that each legislature stayed within its proper subject-matter domain. "From this point on," Larry D. Kramer observes, "the delegates assumed the existence of judicial review over state laws in their deliberations." ${ }^{\text {,55 }}$ It is therefore difficult to exaggerate the importance of the judiciary for the creation of American federalism. Indeed, in the early nineteenth century, the jurisdiction of the federal courts, and the review of state court decisions by the Supreme Court, became a major battleground for competing views of federalism. ${ }^{76}$ Wood's insistence on popular sovereignty as the single causal mechanism for the development of federalism is misguided. As Federalist 78 demonstrates, popular sovereignty was a necessary, but not a sufficient, condition for judicial review. ${ }^{77}$ The move to judicial review, and the adoption of the Supremacy Clause, Article III, and § 8 and $\S 10$ of Article I, was the key moment in which Americans translated multiplicity into operative legal categories.

\section{THEORY}

Perhaps even more troubling than the tone and the substantive arguments in Wood's review is his view of the role of ideas in history and

\footnotetext{
73 Hamburger, Law and Judicial Duty at 17 (cited in note 29). Hamburger continues: "Not merely the arrangement of government, this sort of constitution was the most fundamental part of the law of the land, and although many men questioned its application to Parliament, many others understood it to limit Parliament and thus to render any unconstitutional government act unlawful and void.” Id.

74 The assumption that courts could invalidate legislation was evident in Gouverneur Morris's statement at the convention that "[a] law that ought to be negatived will be set aside in the Judiciary departmt. and if that security should fail; may be repealed by a Nationl. law.” Max Farrand, ed, 2 The Records of the Federal Convention of 178728 (Yale rev ed 1934).

75 Larry D. Kramer, The People Themselves: Popular Constitutionalism and Judicial Review 75 (Oxford 2004) (positing that Luther Martin introduced the Supremacy Clause following defeat of Madison's negative because, as a proponent of states' rights, he wanted to gain support for defeating the negative by offering a palatable alternative).

76 See generally LaCroix, Federalists, Federalism, and Federal Jurisdiction (cited in note 68).

77 In a system of parliamentary sovereignty, such as Britain's after the Glorious Revolution, judicial review of legislative acts was by definition impossible. See Hamburger, Law and Judicial Duty at 238-39 (cited in note 29) (explaining that judges could not hold acts of Parliament unlawful because Parliament was, in theory, the highest common law court).
} 
historiography. Wood creates a stark dichotomy between ideas and experience. In stating that "these early settlers were experiencing federalism without any ideological justification whatsoever," and in relentlessly creating an opposition between the colonists' "experience with governmental multiplicity" on the one hand and the English "idea of sovereignty" on the other, Wood in essence challenges all historians to choose either ideas or experience as causal forces. ${ }^{78}$

Wood charges that I "never make[] clear why ideas were more important than institutions and the day-to-day political experience of the colonists." ${ }^{\text {"79 }}$ My response is that Wood never explains why we must choose between the two. In a book titled The Ideological Origins of American Federalism, one cannot be surprised that the argument does not contain extensive discussion of economic, cultural, or social explanations for the emergence of federalism. My book discuses the ideological origins of American federalism, not the experiential or social origins of American federalism. Wood, however, seems to believe not only that ideology and social practices are mutually exclusive categories, but that social practices are the dominant causal force for historical actors and therefore should be the dominant explanatory factor for historians.

Let us take the first of Wood's statements quoted above as an example. After discussing the Fundamental Orders of Connecticut ${ }^{80}$ as an instance of local self-determination in the early colonial years, he concludes, "All of this reinforced the view that authority was created by the pooling together of local power from below. In other words, these early settlers were experiencing federalism without any ideological justification whatsoever." ${ }^{81}$ Can Gordon Wood, the chief exponent of the concept of republicanism that so influenced much of American political and legal historiography in the late twentieth century, really be saying that "experience" exists as an entirely distinct and neutral category of analysis, separate from any suspicious "ideological justification," and that the presence of any discernible set of social practices means that ideology was irrelevant? Surely by now political, intellectual, and legal historians are sophisticated enough to understand that both social practices and ideology are important-indeed, that they are related and mutually constitutive categories, not that social practices are the important base and ideology

78 Wood, 78 U Chi L Rev at 708, 713 (cited in note 3).

79 Id at 708.

80 Fundamental Orders of Connecticut, 1639, reprinted in Jon L. Wakelyn, ed, 1 America's Founding Charters: Primary Documents of Colonial and Revolutionary Era Governance 125, 125 (Greenwood 2006).

81 Wood, 78 U Chi L Rev at 713 (cited in note 3) (emphasis added). 
merely superstructure. Yet reading Wood's review, one wonders whether he has turned out to be a Beardian after all. ${ }^{82}$

The specifics of his claim seem to be as follows: The early colonists' belief in their own political and constitutional capacity meant that upon arrival in the New World, they were able immediately to set about organizing their own towns and counties, and then colonies and confederations of colonies. From the early decades of the seventeenth century, local political authority was part of everyday life for North American settlers from the British Isles; we know this because they did in fact leave behind documents in which they created towns, counties, colonies, and confederations. Historians do not need to look much further than these documents. In fact, they should not look any further; they should simply take the documents as they are and draw from them the only conclusions that contemporary actors could have drawn: English settlers are compulsive drafters of fundamental political and legal writings; some towns to the north of Long Island Sound have joined themselves into the colony of Connecticut; local units of government are powerful.

With this rich experience of local self-determination-which, again, my book does not dispute but takes as a given - to draw from, the colonists never needed any sort of fancy ideology to justify what they were up to. They simply acted, and their actions were all the evidence we need of what their motivating ideas were. Accounts that emphasize ideas, and that term some ideas "ideologies" when they take on wider political and legal force, and when they both grow out of a particular set of political and legal conditions and feed back into politics and law to reframe the landscape of possibilities, are anathema to the view that Wood puts forth.

The trouble with such a view is that it suggests that the people who were actually having these experiences—colonists in Hartford who helped to draft the Fundamental Orders of Connecticut, passengers aboard the Mayflower who decided not to be deterred by the mismatch between their patent and the location of their landfall—were not thinking about them. The early settlers who, Wood argues, experienced federalism without any ideological justification might have been just mimetic automatons acting on the premise that local units of government are powerful. But Wood is not playing fair here. In order for the practice of localism to become the idea of popular sovereignty that bears so much weight in his interpretation,

\footnotetext{
82 See generally Charles A. Beard, An Economic Interpretation of the Constitution of the United States (Transaction 1988) (originally published 1913) (arguing that economic rather than ideological factors provided the motivating force behind the drafting and ratification of the Constitution). See also Forrest McDonald, Book Review, Colliding with the Past, 25 Rev Am Hist 13, 13-14 (1997) ("To Beard, the establishment of the Constitution was something of a counter-revolution, engineered by affluent but suffering holders of personal as opposed to real property. ... Its design was to reverse the radical democratic tendencies the Revolution had unleashed.”).
} 
contemporary actors must have thought about and attempted to make sense of their experience. Popular sovereignty is, after all, an idea. To argue otherwise would make popular sovereignty nothing more than a post hoc analytical frame conjured by twentieth-century scholars, and neither Wood nor I believes this to be the case.

Perhaps one reason for Wood's hostility to the ideological explanation is simply that it postdates popular sovereignty, which had been present since the earliest days of colonial settlement and which he views as the source of late eighteenth-century American politics. But of course the fact that local autonomy was present from the beginning does not mean that it never changed, much less that federalism was there from the beginning. In order to believe that popular sovereignty was an idea that had meaning for seventeenth- and eighteenth-century Americans, one must take those historical actors seriously enough to believe that they might have been capable of organizing their experiences conceptually. Otherwise, we might as well all be historical materialists, arguing that forces and experiences beyond individual control were responsible for structuring world-historical events. $^{83}$

But that is certainly not what I thought I had learned from the Wood who wrote The Creation of the American Republic, Part One of which is titled "The Ideology of Revolution." " Indeed, the binary view of the distinction between ideas and experience that Wood's review adopts contradicts some of his own most powerful work. Throughout the review, he suggests that the colonial experience of local autonomy was in some important sense "real," while the ideology of multiple authority that I posit was at most an emanation from that reality and not in any important sense real on its own terms. I know I am not alone in having been taught in graduate school that Wood, along with Bernard Bailyn, brought the study of ideas back to American political history after the profession's long dalliance with the materialist and determinist explanations of scholars such as Charles Beard.

In a 1966 article, Wood offered a powerful critique of early to midtwentieth-century Progressive historians such as Beard and Carl Becker, whom he argued had "absorb[ed] the diffused thinking of Marx and Freud and the assumptions of behaviorist psychology" and thus "sought to explain the Revolution and the formation of the Constitution in terms of socioeconomic relationships and interests rather than in terms of ideas." ${ }^{85}$ The

83 See generally Karl Marx, A Contribution to the Critique of Political Economy (Kerr 1913) (N.I. Stone, trans) (originally published 1859); Edwin R.A. Seligman, The Economic Interpretation of History (Gordian 1967) (originally published 1902).

84 Wood, The Creation of the American Republic at 7-8 (cited in note 4).

85 Wood, 23 Wm \& Mary Q at 7 (cited in note 48). See also Beard, An Economic Interpretation of the Constitution at 7 (cited in note 82); Carl Lotus Becker, The History of Political Parties in the Province 
problem with the Progressive historians' approach was that it treated ideas as "parcels of thought to be distributed and used where they would do the most good," in contrast to the more nuanced views of later scholars such as Bailyn, who demonstrated "the autonomy of ideas as phenomena, where the ideas operate, as it were, over the heads of the participants, taking them in directions no one could have foreseen. ${ }^{, 86}$ According to such a methodology, Wood wrote, ideas are "more than indicators of motives. They become as well objects for analysis in and for themselves, historical events in their own right to be treated as other historical events are treated." ${ }^{87}$ For Wood, one important insight that such an interpretation offered was that the Progressive historians' distinction between rhetoric and reality, ideas and interests, was illusory after all. "[T]he ideas, the rhetoric, of the Americans was never obscuring but remarkably revealing of their deepest interests and passions.... [T] political reality; and indeed it becomes the best entry into an understanding of that reality." ${ }^{\prime 8}$ One wonders what the author of those words would have thought of the ideas-experience dichotomy put forth in Wood's review.

Wood has not only misunderstood the substantive claims of my book, but he and I have fundamentally different views of the relationship between ideas and experience, and the associated relationship between law and society. First, ideas and experience. My argument is premised on the notion that social practices take on meaning when contemporaries funnel them through an existing framework of ideas, a process that frequently fundamentally alters that framework. To adapt a line from David Armitage's study of the British Empire, my intention is "not to expose beliefs about" federalism "as either true or false, but rather to show the ways in which the constitutive elements of various conceptions" about federalism "arose in the competitive context of political argument." ${ }^{89}$ Ideas and experience, therefore, should be seen as existing in a relationship of "relative autonomy." ${ }^{\text {"90 }}$ Each is a distinct category, but they are interrelated and mutually constitutive, such that one cannot be understood without the

of New York, 1760-1776 22 (Wisconsin 1960) (originally published 1909); Carl Becker, The Declaration of Independence: A Study in the History of Political Ideas 128-34 (Harcourt, Brace 1922).

86 Wood, 23 Wm \& Mary Q at 8-10, 23 (cited in note 48).

87 Id at 21.

88 Id at 31 (arguing that the colonists' "repeated overstatements"- -such as "incessant talk of 'tyranny,", "obsession with 'virtue,"” and "devotion to 'liberty"”-were ideas of "real personal and social significance” based in their own experience rather than mere propaganda).

89 David Armitage, The Ideological Origins of the British Empire 5 (Cambridge 2000).

90 See Robert W. Gordon, Critical Legal Histories, 36 Stan L Rev 57, 100-01 (1984) (“[Legal doctrines] can't be explained completely by reference to external political/social/economic factors. To some extent they are independent variables in social experience and therefore they require study elaborating their peculiar internal structures.”). See also Morton J. Horwitz, The Transformation of American Law, 17801860 xiii (Harvard 1977) (arguing that "legal consciousness in any particular period is not simply the sum of those contemporary social forces that impinge upon law”). 
other-either by contemporaries or by later historians looking back at a given moment.

This view has important consequences for the study of legal and constitutional thought. As Morton Horwitz observes, "no historian of law can fail to recognize that legal consciousness in any particular period is not simply the sum of those contemporary social forces that impinge upon law. Law is autonomous to the extent that ideas are autonomous, at least in the short run." ${ }^{\text {91 }}$ Wood's distinction between experience and ideas, and his disdain for ideological explanations, is simply untenable when applied to the study of the history of a legal concept such as federalism. Unless Wood did not really mean it when he stated that federalism is "a historically created conception that changed through time as circumstances changed" rather than a "transcendent idea standing outside of time and place," ${ }^{, 92}$ it is difficult to understand his resistance to an ideological history-any ideological history, it would seem-of federalism. Federalism was the subject of a great deal of thought and discussion by lawyers, which may or may not have reflected social practice. Once we accept the relative autonomy of law, however, the difficulties with Wood's "mirror theory" of law as merely the reflection of experience-and therefore of federalism as nothing more than the logical outcome of local political autonomybecome evident. ${ }^{93}$ It is not a meaningful critique to say that the ideological account of federalism's origins does not match the experiential account. While ideas and experience, and law and social practice, are deeply interrelated, they are not the same thing. In contrast to the mirror theory of law, the view of experience and ideas as mutually constitutive recognizes that change in law and change in social practice can and do take place at different rates. The widespread political decentralization that characterized early colonial America did not create a reality that law simply followed. Legal thought drew from a variety of sources and influences, and as James Otis's struggle illustrates, the intellectual path from local legislative authority to the constitutionalization of federal law as the supreme law of the land, binding on state judicial officers, was difficult to navigate.

\section{CONCLUSION}

In his review, Wood sets forth more clearly than he has elsewhere his view of the relationship between republicanism and federalism. For Wood, republicanism-defined above all as popular sovereignty-was the proximate cause of the Revolution and the drafting and ratification of the

91 Horwitz, Transformation of American Law at xiii (cited in note 90).

92 Wood, 78 U Chi L Rev at 708 (cited in note 3).

93 See William Ewald, Comparative Jurisprudence (II): The Logic of Legal Transplants, 43 Am J Comp L 489, 491-96, 508 (1995) (describing and critiquing “mirror theories of law”). 
Constitution. On this view, the changes in late eighteenth-century American political and legal theory can be explained only and entirely by republican ideology, which in his review is presented as the sum of the colonists' decades-long experience of local autonomy. Federalism was simply an outgrowth of this ideology, an application of the general principle of popular sovereignty to the specific problem of the relationship between the states and the general government.

My book is a history of the shift from multiplicity as a problematic but deeply felt commitment of British North American legal thought to federalism as the foundational constitutional value behind a new legal and political regime. To be sure, the new regime was a republic, and it therefore relied on republican ideas, among them popular sovereignty. But the new regime was also federal, and it therefore emerged from a diffuse array of responses, both theoretical and experiential, to unitary sovereignty. Federalism was not just the result of Americans finally internalizing the fear of imperium in imperio and finding the language to describe their homegrown remedy for it. Federalism was a rejection of that specter based on both their experience with local government and their theory that sovereignty could be divided along subject-matter lines, lines that would in turn be policed by an institution with a special mandate to monitor these boundaries.

If Wood charges me with originality because I view American federalism as distinct from republicanism, I am happy to accept the compliment. 
Readers with comments may address them to:

Professor Alison L. LaCroix

University of Chicago Law School

1111 East 60th Street

Chicago, IL 60637

lacroix@uchicago.edu 


\section{The University of Chicago Law School Public Law and Legal Theory Working Paper Series}

For a listing of papers 1-300 please go to http://www.law.uchicago.edu/publications/papers/publiclaw.

300. Anu Bradford, When the WTO Works, and How It Fails (March 2010)

301. Aziz Z. Huq, Modeling Terrorist Radicalization (March 2010)

302. Adam M. Samaha, On Law's Tiebreakers (March 2010)

303. Brian Leiter, The Radicalism of Legal Positivism (March 2010)

304. Lee Anne Fennell, Unbundling Risk (April 2010)

305. Aziz Z. Huq, What Good Is Habeas? (April 2010)

306. Aziz Z. Huq, Easterbrook on Academic Freedom (April 2010)

307. Jonathan S. Masur and Jonathan Remy Nash, The Institutional Dynamics of Transition Relief (April 2010)

308. Alison L. LaCroix, Temporal Imperialism (May 2010)

309. Lior J. Strahilevitz, Reunifying Privacy Law (May 2010)

310. Lee Fennell, Possession Puzzles (June 2010)

311. Jonathan S. Masur, Booker Reconsidered (June 2010)

312. Mary Anne Case, What Feminists Have to Lose in Same-Sex Marriage Litigation (July 2010)

313. Mary Anne Case, A Lot to Ask: Review Essay of Martha Nussbaum's From Disgust to Humanity: Sexual Orientation and Constitutional Law (July 2010)

314. Adam M. Samaha, The Story of FCC v. Pacifica Foundation (and Its Second Life) (August 2010)

315. Jonathan S. Masur and Eric A. Posner, Climate Regulation and the Limits of Cost-Benefit Analysis (August 2010)

316. Jonathan Masur, Patent Inflation (August 2010)

317. Bernard E. Harcourt and Tracey L. Meares, Randomization and the Fourth Amendment (August 2010)

318. Adam M. Samaha, Low Stakes and Constitutional Interpretation (August 2010)

319. Brian Leiter, The Demarcation Problem in Jurisprudence: A New Case for Skepticism (August 2010)

320. Brian Leiter, Legal Formalism and Legal Realism: What Is the Issue? (August 2010)

321. John Bronsteen, Christopher Buccafusco, and Jonathan S. Masur, Retribution and the Experience of Punishment (September 2010)

322. Lior Strahilevitz, Pseudonymous Litigation (September 2010)

323. Bernard E. Harcourt, Risk As a Proxy for Race (September 2010)

324. Christopher R. Berry and Jacob E. Gersen, Voters, Non-Voters, and the Implications of Election Timing for Public Policy, September 2010

325. Lee Anne Fennell, Willpower Taxes, October 2010

326. Christopher R. Berry and Jacob E. Gersen, Agency Design and Distributive Politics, October 2010

327. Eric A. Posner, The Constitution of the Roman Republic: A Political Economy Perspective, November 2010

328. Tom Ginsburg, James Melton and Zachary Elkins, On the Evasion of Executive Term Limits, November 2010

329. Rosalind Dixon and Eric A. Posner, The Limits of Constitutional Convergence, November 2010

330. Tom Ginsburg, Constitutional Specificity, Unwritten Understandings and Constitutional Agreement, November 2010. 
331. Tom Ginsburg, Written Constitutions and the Administrative State: On the Constitutional Character of Administrative Law, November 2010

332. Rosalind Dixon, Amending Constituting Identity, December 2010

333. Eric A. Posner and Adrian Vermeule, Demystifying Schmitt, January 2011

334. Jonathan S. Masur, Regulating Patents, January 2011

335. Bernard E. Harcourt, Reducing Mass Incarceration: Lessons from the Deinstitutionalization of Mental Hospitals in the 1960s, January 2011

336. Jacob E. Gersen, Designing Agencies, January 2011

337. Stephen J. Schulhofer, Tom R. Tyler, and Aziz Z. Huq, American Policing at a Crossroads, February 2011

338. Aziz Z. Huq, The Signaling Function of Religious Speech in Domestic Counterterrorism, February 2011

339. Aziz Z. Huq, Tom R. Tyler, and Stephen J. Schulhofer, Why Does the Public Cooperate with Law Enforcement? The Influence of the Purposes and Targets of Policing, February 2011

340. Aziz Z. Huq, Tom R. Tyler, and Stephen J. Schulhofer, Mechanisms for Eliciting Cooperation in Counter-Terrorism Policing: Evidence from the United Kingdom

341. Bernard E. Harcourt, Making Willing Bodies: Manufacturing Consent among Prisoners and Soldiers, Creating Human Subjects, Patriots, and Everyday Citizens-The University of Chicago Malaria Experiments on Prisoners at Stateville Penitentiary, February 2011

342. Jonathan S. Masur, Patent Liability Rules as Search Rules, February 2011

343. Brian Leiter, The Law of Religious Liberty in a Tolerant Society, March 2011

344. Rosalind Dixon, Updating Constitutional Rules, March 2011

345. Rosalind Dixon and Martha Nussbaum, Abortion, Dignity and a Capabilities Approach, March 2011

346. Rosalind Dixon and Richard Holden, Constitutional Amendment Rules: The Denominator Problem, May 2011

347. Rosalind Dixon, Constitutional Amendment Rules: A Comparative Perspective, May 2011

348. Rosalind Dixon, Weak-Form Judicial Review and American Exceptionalism, May 2011

349. Rosalind Dixon, Transnational Constitutionalism and Unconstitutional Constitutional Amendments, May 2011

350. Adam B. Cox and Richard T. Holden, Reconsidering Racial and Partisan Gerrymandering, May 2011

351. Brian Leiter, The Circumstances of Civility, May 2011

352. Brian Leiter, Naturalized Jurisprucence and American Legal Realism Revisited, May 2011

353. Lee Anne Fennell, Property and Precaution, June 2011

354. Alon Harel and Ariel Porat, Commensurability and Agency: Two Yet-to-Be-Met Challenges for Law and Economics, June 2011

355. Bernard E. Harcourt, Radical Throught from Marx, Nietzsche, and Freud, through Foucault, to the Present: Comments on Steven Lukes' "In Defense of False Consciousness,” June 2011

356. Alison L. LaCroix, Rhetoric and Reality in Early American Legal History: A Reply to Gordon Wood, July 2011 